\title{
Effect of Duration of Olive Storage on Chemical and Sensory Quality of Extra Virgin Olive Oils
}

\author{
Annalisa Rotondi, Lucia Morrone *(D), Gianpaolo Bertazza and Luisa Neri (D) \\ Institute for the Bioeconomy, Italian National Research Council, via P. Gobetti 101, 40129 Bologna, Italy; \\ annalisa.rotondi@ibe.cnr.it (A.R.); gianpaolo.bertazza@ibe.cnr.it (G.B.); luisa.neri@ibe.cnr.it (L.N.) \\ * Correspondence: lucia.morrone@ibe.cnr.it
}

Citation: Rotondi, A.; Morrone, L.; Bertazza, G.; Neri, L. Effect of Duration of Olive Storage on Chemical and Sensory Quality of Extra Virgin Olive Oils. Foods 2021, 10, 2296. https://doi.org/10.3390/ foods10102296

Academic Editor: Theodoros Varzakas

Received: 16 September 2021 Accepted: 23 September 2021 Published: 28 September 2021

Publisher's Note: MDPI stays neutral with regard to jurisdictional claims in published maps and institutional affiliations.

Copyright: (c) 2021 by the authors. Licensee MDPI, Basel, Switzerland. This article is an open access article distributed under the terms and conditions of the Creative Commons Attribution (CC BY) license (https:/ / creativecommons.org/licenses/by/ $4.0 /)$.

\begin{abstract}
This work considered the influence of the duration of olive storage on the chemical and sensory properties of extra virgin olive oil. In total, 228 batches of olives collected during three successive crop seasons were sampled in seven industrial mills; information about olive batches (variety, harvest date) was collected, together with the produced oils. Four classes of storage times were considered: $\leq 24 \mathrm{~h}, 2-3$ days, $4-6$ days, $\geq 7$ days. The oils' quality parameters free acidity, peroxide number and K232 increased significantly as storage duration increased, while phenolic content decreased significantly, with a resulting effect on oil stability. The fatty acid composition was not affected by the olive storage period, while $\alpha$-tocopherol, lutein and $\beta$-carotene content decreased as storage duration lengthened. Finally, the main positive sensory attributes (olive fruity, green notes, bitter and pungency) underwent a statistically significant reduction with the increase in storage duration, while the intensity of defects increased, suggesting that the duration of olive storage has an important effect on the quality of the final oil.
\end{abstract}

Keywords: olive oil; olive storage duration; oil chemical composition; sensory properties

\section{Introduction}

Olive oil plays an important role in the diet in Mediterranean countries [1]. Extra virgin olive oil (EVOO) is the only vegetable oil that must be extracted only by mechanical means without any adjuvants [2]. EVOO is therefore, in effect, a fruit juice, hence the phytosanitary state of drupes is the main factor determining the quality of the extracted olive oil [3]. To best preserve the raw material before processing, post-harvest management is strategic to obtain extra virgin olive oils, since during this period oxidation of fat matrix and fermentation can occur [4].

However, in olive-producing regions such as Italy, Spain and Greece, because of the difficulty in synchronizing fruit harvesting and extraction of its oil, the olive sector is often forced to store the fruits piled up, in poor conditions and for periods of up to several weeks. During this period, the fruits suffer mechanical, physicochemical and physiological alterations that may eventually cause the breakdown of their cell structures [5,6]. During prolonged olive storage, anaerobiosis processes can occur in the lower portion of the olives kept inside the containers, and heat production from the respiratory activity may also accelerate fruit deterioration and eventually cause the breakdown of the cell structure [6]. Olive oils obtained from damaged olives present a characteristic high acidity, low oxidative stability and high level of oxidation, due to the increased peroxide value, and specific extinction coefficients at 232 and 270; they can also develop a high content of volatile acids (acetic or butyric) that cause a typical musty smell [7]. These processes will deteriorate the chemical and sensory quality of the resulting EVOO, so in order to better manage the postharvest period, several technological solutions have been proposed such as cold storage of olives [7], storage in a modified atmosphere [8], and other preservation conditions such as storage in sea water, brine or drinking water have also been investigated [9]. 
The importance of processing olives a short time after harvesting is also linked to the fact that most fruit is harvested mechanically and could, therefore, be internally damaged, more so than in the case of manual harvesting; however, allowing for proper storage conditions the fruits can be stored for several days maintaining the appropriate chemical and sensory quality standards of the final oil. Yousfi et al. [10], in fact, studied the quality of EVOO from mechanically harvested Arbequina olives under different storage conditions, and found that storage at $3{ }^{\circ} \mathrm{C}$ for a period of up to 10 days allowed the highest commercial level of oil quality to be maintained.

The problem of synchronization of harvest and transformation phases has not been widely considered in Italy, where this study was carried out in the past due to the production fragmentation, the structure of olive mills (small and widespread) and the presence of different olive cultivars, a factor broadening the collection window. However, the presence of numerous different cultivars on the Italian territory is a characteristic feature of Italian olive growing that increases its sustainability as the loss of biodiversity is an environmental threat. The production of monovarietal olive oils has increased to a great extent lately since the quality of olive oil depends on the olive variety from which it originates [11]. Nowadays, however, the structure of production is changing in Italy, due to the presence of an increasing number of intensive orchards that can exceed the processing capacity of the mills, and therefore synchronization between harvest and transformation should be considered.

The aim of this study was to assess the effect of the duration of olive storage on the chemical and sensory quality of the EVOO, identifying which parameters were most affected by olive storage; in particular, we focused on product parameters that are more easily illustrated to actors in the supply chain (mills, producers and consumers), thus making it easier to understand and assimilate the results.

\section{Materials and Methods}

\subsection{Olive Fruit Analysis and Oil Sampling}

Olive fruits and the corresponding oil samples $(n=228)$ were collected during $3 \mathrm{crop}$ seasons, from seven industrial oil mills located in the Emilia-Romagna region in northern Italy, all equipped with hammer crusher, two-phase decanter, and centrifugation and filtration facilities. Data characterising olive oil samples, such as olive cultivar, harvesting method, and olive storage duration, were collected by interviewing olive growers. Only samples of healthy olives without signs of infection were considered after visual inspection.

Oil samples were poured into dark glass bottles, keeping headspace to a minimum, and stored in the dark in a temperature-controlled cupboard set at $15 \pm 1^{\circ} \mathrm{C}$, until chemical and sensory analyses were carried out.

\subsection{Chemical Analysis of Olive Oils}

Free acidity, peroxide value, and UV-spectrophotometric indices (K232, K270) were evaluated in triplicate in line with official methods described in Regulation EC 2568/91 and subsequent amendments [12].

Analysis of fatty acids was carried out according to Regulation EC 2568/91 and subsequent amendments [12] using a Chrompack CP 9000 gas chromatograph with a flame ionization detector (FID), equipped with a capillary column (Stabilwax, Restek Corporation, Bellefonte, PA, USA) and helium as the carrier gas (flow rate $=1 \mathrm{~mL} \mathrm{~min}^{-1}$; split ratio of 1:20, $\mathrm{v}: \mathrm{v})$. Chromatographic parameters were as follows: injection and detection temperature $250{ }^{\circ} \mathrm{C} ; 230^{\circ} \mathrm{C}$; column oven temperature, $240{ }^{\circ} \mathrm{C}$. All parameters were determined in triplicate for each sample.

The phenolic fraction was extracted in triplicate from $30 \mathrm{~g}$ of oil using $30 \mathrm{~mL}$ of methanol. The combined extract was brought to dryness through a rotary evaporator and then suspended in $2 \mathrm{~mL} \mathrm{50 \%} \mathrm{methanolic} \mathrm{solution.} \mathrm{Total} \mathrm{phenol} \mathrm{content} \mathrm{was} \mathrm{determined} \mathrm{by}$ the Folin-Ciocalteau spectrophotometric method at $750 \mathrm{~nm}$ [13] using a spectrophometer (Jasco V-500, Jasco Corporation, Tokyo, Japan). 
Quantitative analysis of tocopherols, lutein and $\beta$-carotene was carried through olive oil filtration on PTFE (Polytetrafluoroethylene) membrane filter of $25 \mathrm{~mm}, 0.2 \mu \mathrm{m}$ pore size (GyroDisc, Orange Scientific, Waterloo, Belgium) and direct injection of $20 \mu \mathrm{L}$ in HPLC (high-performance liquid chromatography) [14] equipment (LC-10ADvp, Shimadzu, Kyoto, Japan) with a degasser (Flow 154, Gastorr Flom, Tokyo, Japan), a low-pressure gradient unit (FCV-10ALvp, Shimadzu, Kyoto, Japan) and a column oven (CTO-10ASvp, Shimadzu, Kyoto, Japan). Analytes were separated on a C18 column $150 \mathrm{~mm} \times 4.6 \mathrm{~mm}$ (Inertsil ODS-2 5U, Alltech, Deerfield, IL, USA); the flow rate was $1 \mathrm{~mL} \mathrm{~min}^{-1}$, the injection volume was $20 \mu \mathrm{L}$ and the column temperature was $25{ }^{\circ} \mathrm{C}$. The eluent used was: A methanol: water 80:20 $(v / v)$ and B methanol: tetrahydrofuran 20:80 $(v / v)$. Quantification of analytes was carried out using their relative analytical standard's calibration curves all purchased from Merk (Deisenhofen, Germany). Tocopherol quantification was carried out at $295 \mathrm{~nm}$, $\beta$-carotene and lutein at $450 \mathrm{~nm}$ using a photodiode array detector (UV6000, ThermoQuest, San Jose, CA, USA).

\subsection{Oil Stability Determination}

For determination of oil stability, an eight-channel Oxidative Stability Instrument (OSI) (Omnion, Decatur, IL, USA) was used; the instrument was set at $110{ }^{\circ} \mathrm{C}$ and at $120 \mathrm{~mL} \mathrm{~min}^{-1}$ (airflow) [15]. The OSI index was expressed as time (hours and hundredth of hours) and was reported as "OSI time".

\subsection{Sensory Analysis}

Sensory analysis was performed by the panel of Agency for Agrofood Sector Services of Marche region (ASSAM), a fully-trained analytical taste panel recognized by the International Olive Oil Council (IOC) of Madrid, Spain, and by the Italian Ministry for Agriculture, Food, and Forestry Policy. The panel was composed of 8 assessors, 50\% male and $50 \%$ female. The method applied was QDA (Quantitative Descriptive Analysis). A profile sheet IOC method T20 n. 15 modified by IBIMET-CNR and ASSAM was used, allowing to obtain a QDA of the oils' sensory profile and more complete description of the organoleptic properties of the sampled oils: the sensory assessors evaluated direct or retronasal aromatic olfactory sensations (aroma of olive fruity and green notes), gustatory sensations (olive fruity and bitterness) and tactile/kinesthetic sensation (pungency), organoleptic defects (Supplementary Table S1) as well as overall judgment. The sensory assessors had to rate the intensity of the different descriptors on a continuous $0-10 \mathrm{~cm}$ scale. Values of median of sensory data were calculated.

\subsection{Statistical Analysis}

The significance of differences at a $5 \%$ level was determined by one-way ANOVA using Tukey's test with Microsoft ${ }^{\circledR}$ Excel 2007/XLSTAT@ (Version 2009.3.02, Addinsoft, Inc., Brooklyn, NY, USA). Sensory data were also processed for Principal Component Analysis (PCA) to explore data distribution patterns and to visualize the "distance" between oils produced following the differing storage times.

\section{Results and Discussion}

After interviewing olive growers, it was recorded that the olive and the correspondent Extra virgin olive oil (EVOO) samples collected $(n=228)$ were mainly composed of mixed varieties (blends) $(45 \%)$, while the remaining samples were monovarietal from cv. Nostrana di Brisighella (25\%), cv. Correggiolo (16\%), cv. Leccino (8\%) and other minor cultivars (6\%). Furthermore, it was assessed that the olives' storage method was the same for all the analyzed samples: fruits were stored in small plastic bins with holes to allow for ventilation, and never in stacks nor in plastic or jute bags.

Olive storage duration before technological transformation ranged from 0 to over 7 days: chemical and sensory data were thus processed dividing them into four classes of storage times: $\leq 24 \mathrm{~h}, 2-3$ days, $4-6$ days, $\geq 7$ days. Only $39 \%$ of olive samples were pro- 
cessed within $24 \mathrm{~h}$, while $23 \%$ and $20 \%$ of olive samples were stored between 2 and 3 days and between 4 and 6 days, respectively; finally, 18\% of samples were processed after 7 days of storage.

The content of free acids is an important quality factor, extensively used as the major criterion for the classification of olive oil at various commercial grades [16]. The values of free acidity, peroxide number, and K232 increased significantly along with the increase in olive storage duration (Table 1). There was a free acidity increase from $0.30 \%$ to $0.56 \%$ during the olive storage period studied; peroxide number from 6.96 to $9.56 \mathrm{mEqO}_{2} \mathrm{~kg}^{-1}$, K232 from 1.48 to 1.66 while K270 was not affected by time of storage probably because indicates secondary oxidation. It is interesting to note that all these values fall within the legal limit of the classification of extra virgin olive oil. This indicates that, although the oxidation process starts to take place during the olives' storage time, the phytosanitary state and the integrity of the raw material affect the speed of this process. The total phenol content of oil samples suffered a progressive reduction as olive storage duration proceeded: as observed in Table 1, oils produced within $24 \mathrm{~h}$ from the olive collection had a phenolic content of $243 \mathrm{mg} \mathrm{kg}^{-1}$ of gallic acid while oils produced from olives stored for over 7 days presented $143.6 \mathrm{mg} \mathrm{kg}^{-1}$ of gallic acid, a decrease of $41 \%$. This phenol loss could be attributed both to bacteria and fungi proliferation on cellular fluid exuding from damaged fruits [17] and to endogenous oxidoreductases [18] as suggested by Clodoveo et al. [5], results of which were consistent with the data presented here. This impoverishment in the phenol fraction also affected the oils' stability, with a reduction from $28 \mathrm{~h}$ in oils produced within a day to $19 \mathrm{~h}$ in oils obtained from olives stored for more than a week, with a decrease of 30\% (Table 1). These results agree with the studies of Vichi et al. [19] and Youssef et al. [20]. Our results partially agree with Pereira et al. [21], which found a significant decrease in oil stability during the first period of storage (0-7 days), while for peroxide number, free acidity and K232 and K270 the values were not significantly affected by storage duration. As explained by Pereira himself [21], the verified decrease in stability was due to the consumption of minor compounds such as phenols and tocopherols, that hindered the formation of peroxides.

Table 1. Quality index of oil samples extracted after different olive storage duration. Values are mean \pm standard deviation. Values followed by different letters in the same column $(a, b, c)$ were significantly different according to Tukey's test $(p<0.05)$.

\begin{tabular}{|c|c|c|c|c|c|c|}
\hline Storage Classes & Free Acidity & Peroxide Number & K232 & K270 & Total Phenol & OSI \\
\hline$<24 \mathrm{~h}$ & $0.30 \pm 0.09 \mathrm{~b}$ & $6.96 \pm 2.17 b$ & $1.48 \pm 0.18 \mathrm{~b}$ & $0.08 \pm 0.02$ & $246.00 \pm 104.02 \mathrm{a}$ & $28.28 \pm 10.83 a$ \\
\hline $2-3$ days & $0.37 \pm 0.17 \mathrm{~b}$ & $9.03 \pm 2.76 \mathrm{a}$ & $1.64 \pm 0.23 \mathrm{a}$ & $0.09 \pm 0.02$ & $202.51 \pm 90.14 b$ & $22.60 \pm 7.53 b$ \\
\hline 4-6 days & $0.51 \pm 0.36 \mathrm{a}$ & $8.67 \pm 2.94 \mathrm{a}$ & $1.55 \pm 0.25 \mathrm{ab}$ & $0.08 \pm 0.02$ & $179.22 \pm 83.49 \mathrm{bc}$ & $16.90 \pm 5.74 b$ \\
\hline$>7$ days & $0.56 \pm 0.43 \mathrm{a}$ & $9.56 \pm 2.64 \mathrm{a}$ & $1.66 \pm 0.29 \mathrm{a}$ & $0.09 \pm 0.02$ & $143.60 \pm 63.39 c$ & $19.91 \pm 10.08 b$ \\
\hline$p$-value & $<0.0001$ & $<0.0001$ & $<0.0001$ & 0.394 & $<0.0001$ & $<0.0001$ \\
\hline
\end{tabular}

Free acidity is expressed as $\mathrm{g} / 100 \mathrm{~g}$ of oleic acid; peroxide number as $\mathrm{mEq}_{2} \mathrm{~kg}^{-1}$ oil; OSI, oxidative stability index, as hours; total phenol as $\mathrm{mg} \mathrm{kg}^{-1}$ of gallic acid.

Fatty acid and sterolic profile can be used as an exceptional compositional marker for olive oil authenticity [11]. Fatty acid composition of all of the EVOO samples extracted from olives after different storage duration was characterized by the high oleic acid content (Table 2), coherent with the cold climate of the region; the relationship between fatty acid composition and climate is well known [22]. Several studies reported that fatty acid composition in oils did not show any change as the period for which olives were stored prior to crushing increased $[10,23]$ and neither did they even when the olive storage period was very long, e.g., 45 days, as reported by Gutierrez et al. [24]. However, other studies $[20,21]$ found differences in fatty acids content during storage, in agreement with our results. Specifically, we found differences in the content of C16:0, C18:1 and C18:2. In fact, the $\mathrm{C} 16: 0$ content tended to increase as the olive storage period lengthened, while concentrations of $\mathrm{C} 18: 1$ and $\mathrm{C} 18: 2$ did not show a clear trend. 
Table 2. Fatty acid composition of oils produced by olives after different olive storage duration. Values are mean \pm standard deviation. Values followed by different letters in the same column $(a, b)$ were significantly different according to Tukey's test $(p<0.05)$.

\begin{tabular}{ccccccc}
\hline Storage Classes & C16 & C16:1 & C18 & C18:1 & C18:2 & C18:3 \\
\hline$<24 \mathrm{~h}$ & $12.67 \pm 0.96 \mathrm{~b}$ & $1.25 \pm 0.26$ & $2.09 \pm 0.23$ & $75.39 \pm 1.48 \mathrm{a}$ & $6.74 \pm 0.98 \mathrm{~b}$ & $0.74 \pm 0.09$ \\
2-3 days & $13.07 \pm 0.73 \mathrm{ab}$ & $1.2 \pm 0.18$ & $2.03 \pm 0.25$ & $75.02 \pm 1.53 \mathrm{ab}$ & $6.97 \pm 1.07 \mathrm{ab}$ & $0.71 \pm 0.07$ \\
4-6 days & $13.17 \pm 1.05 \mathrm{a}$ & $1.2 \pm 0.17$ & $2.04 \pm 0.19$ & $74.49 \pm 1.80 \mathrm{~b}$ & $7.31 \pm 1.18 \mathrm{a}$ & $0.73 \pm 0.08$ \\
$>$ d days & $13.15 \pm 0.76 \mathrm{a}$ & $1.15 \pm 0.16$ & $1.99 \pm 0.16$ & $75.17 \pm 1.61 \mathrm{ab}$ & $6.75 \pm 1.16 \mathrm{ab}$ & $0.73 \pm 0.08$ \\
$p$-value & 0.004 & 0.071 & 0.089 & 0.020 & 0.026 & 0.213 \\
\hline
\end{tabular}

The content of $\alpha$-tocopherol, the naturally occurring form of vitamin E assimilated by the human body, found in oils obtained from olives belonging to different conservation classes showed a statistically significant decreasing trend (Table 3). Vitamin E is an antioxidant, working as peroxyl radical scavenger that terminates chain reactions [25]. As it is well documented, oxidation phenomena are the main cause of tocopherol degradation [26]; the data here presented showed that milling olives within $24 \mathrm{~h}$ from the collection was the only way to protect the tocopherol fraction. In this study, the decrement in $\alpha$-tocopherol content found after 7 days of olive storage was about $17 \%$, consistent with the reduction of $22 \%$ of total tocopherol content found by Yousfi et al. [10] for cv. Arbequina and Pereira and colleagues [21] for cv. Verdeal Transmontana. An important and significant decrease in $\alpha$-tocopherol after a short $(48 \mathrm{~h}$ ) olive storage period was as well found for $\mathrm{cv}$. Nostrana di Brisighella oils while not for cv. Correggiolo oils [27].

Table 3. Tocopherol and carotenoid content in oil samples after different olive storage durations. Values are mean \pm standard deviation. Compounds are expressed as $\mathrm{mg}$ of relative standard compound per $\mathrm{kg}$ of oil. Values followed by different letters in the same column $(\mathrm{a}, \mathrm{b})$ were significantly different according to Tukey's test $(p<0.05)$.

\begin{tabular}{ccccc}
\hline Storage Classes & $\alpha$-Tocopherol & $\beta+\gamma$-Tocopherol & Lutein & $\beta$ Carotene \\
\hline$<24 \mathrm{~h}$ & $184.25 \pm 36.59 \mathrm{a}$ & $8.29 \pm 1.84$ & $1.67 \pm 0.62 \mathrm{a}$ & $1.05 \pm 0.63 \mathrm{a}$ \\
$2-3$ days & $165.63 \pm 32.8 \mathrm{~b}$ & $8.31 \pm 2.32$ & $1.34 \pm 0.94 \mathrm{~b}$ & $0.80 \pm 0.68 \mathrm{~b}$ \\
$4-6$ days & $160.98 \pm 32.85 \mathrm{~b}$ & $8.33 \pm 2.07$ & $1.19 \pm 0.42 \mathrm{~b}$ & $0.64 \pm 0.41 \mathrm{~b}$ \\
$>7$ days & $157.77 \pm 30.96 \mathrm{~b}$ & $8.24 \pm 1.80$ & $1.46 \pm 0.46 \mathrm{ab}$ & $0.82 \pm 0.34 \mathrm{~b}$ \\
$p$-value & $<0.0001$ & 0.988 & 0.000 & 0.000 \\
\hline
\end{tabular}

In the present study, carotenoid pigments decreased during the first three storage times analyzed, in agreement with other works [28,29]. At the last time of storage duration analyzed ( $>7$ days), olive oils showed an increase in carotenoid content, in line with Yousfi and colleagues [10], who hypothesized a greater extractability of the pigments in olives during storage, due to the degradation of the chloroplast membranes; the degradation was found to be a consequence of the growing dehydration of the olives during storage [10].

A correlation analysis was carried out to quantify the intensity of the connection between EVOO properties and olive storage duration (Table 4). A positive correlation (Pearson) with storage duration was found for the parameter acidity, peroxide number, K232 and palmitic acid content, while palmitoleic and stearic acid, total phenol content and oil stability exhibited a negative correlation, diminishing with the increase in storage duration. In the case of fruits left for long periods before transformation, in the produced oils was observed, in addition to an increase in free acidity, even a gradual depletion in the content of oleic acid and total phenols, with the consequent reduction in stability during storage. It is also important to underline the correlation $(\mathrm{r}=0.388, p \leq 0.0001)$ between oleic acid and OSI found in this work (data not shown). In fact, a high concentration of oleic acid enhances the oil stability and EVOO oxidative stability is mainly linked to its fatty acid composition, therefore the induction period is the result of the fatty acid composition and the simultaneous activity of various prooxidant and antioxidant factors endogenous in the oils [30]. 
Table 4. Pearson correlation between oil chemical parameters and olive storage duration.

\begin{tabular}{ccc}
\hline Variable & $\mathbf{r}$ & $p$ \\
\hline Acidity & 0.244 & 0.000 \\
Peroxide number & 0.312 & $<0.0001$ \\
Total phenols & -0.319 & $<0.0001$ \\
C 16 & 0.149 & 0.031 \\
C 16:1 & -0.184 & 0.007 \\
C 18 & -0.139 & 0.044 \\
C 18:1 & -0.009 & 0.894 \\
C 18:2 & -0.038 & 0.587 \\
C 18:3 & -0.021 & 0.757 \\
OSI & -0.262 & 0.000 \\
$K_{232}$ & 0.295 & $<0.0001$ \\
$\mathrm{~K}_{270}$ & 0.035 & 0.615 \\
\hline
\end{tabular}

The sensory profile was modified according to the olive storage duration before processing, with the main positive attributes (olive fruity, green notes, bitterness and pungency) undergoing a statistically significant reduction with the increasing of olive storage days (Table 5). This result was in line with the previously recorded decrease in total phenols: the typical bitter taste and pungent note of fresh EVOO rich in total phenols decreased in intensity as olive storage duration lengthened. The intensity of the defects perceived by the sensory assessors increased with the progress of the days of olives storage (Table 5). Even in oils processed within $24 \mathrm{~h}$, an intensity of the defect of 0.29 was recorded, probably attributable to the percentage of olives harvested late and thus overripe. In detail, the perceived defects were attributable to incorrect management of the raw material: in fact, they were $67 \%$ for the fusty defect, $29 \%$ for the vinegary and only $4 \%$ for the musty defect. During prolonged olive storage duration, the drupe tissues are damaged, resulting in the secretion of fluids favoring the growth of undesirable microorganisms [17]; increased temperature can also increase drupe respiratory activity, leading to undesirable metabolic processes accelerating fruit deterioration and characterized by the fusty sensory defect [31].

Table 5. The intensity of sensory attributes (aroma of olive fruity and green notes, flavor of bitterness, pungency and defect) of oil samples related to different olive time storage. Values are median \pm standard deviation. Values followed by different letters in the same column $(a, b, c)$ were significantly different according to Tukey's test $(p<0.05)$.

\begin{tabular}{cccccc}
\hline Storage Classes & Olive Fruity & Green Notes & Bitterness & Pungency & Defect \\
\hline$<24 \mathrm{~h}$ & $2.25 \pm 0.5 \mathrm{a}$ & $1.36 \pm 0.65 \mathrm{a}$ & $2.16 \pm 0.76 \mathrm{a}$ & $1.93 \pm 0.52 \mathrm{a}$ & $0.29 \pm 0.55 \mathrm{~b}$ \\
$2-3$ days & $1.98 \pm 0.45 \mathrm{~b}$ & $0.92 \pm 0.54 \mathrm{~b}$ & $1.76 \pm 0.62 \mathrm{~b}$ & $1.74 \pm 0.46 \mathrm{ab}$ & $0.34 \pm 0.50 \mathrm{~b}$ \\
$4-6$ days & $1.79 \pm 0.41 \mathrm{~b}$ & $0.64 \pm 0.51 \mathrm{~b}$ & $1.35 \pm 0.53 \mathrm{c}$ & $1.43 \pm 0.46 \mathrm{c}$ & $0.79 \pm 0.76 \mathrm{a}$ \\
$>7$ days & $1.75 \pm 0.38 \mathrm{~b}$ & $0.57 \pm 0.43 \mathrm{~b}$ & $1.4 \pm 0.65 \mathrm{bc}$ & $1.41 \pm 0.51 \mathrm{bc}$ & $0.57 \pm 0.64 \mathrm{~b}$ \\
$p$-value & $<0.0001$ & $<0.0001$ & $<0.0001$ & $<0.0001$ & $<0.0001$ \\
\hline
\end{tabular}

The Principal Component Analysis (PCA) of the sensory data explained $91.4 \%$ of the variability and confirmed the strong influence of olive storage duration on the sensory characteristics of the oils produced (Figure 1). Most of the samples that transformed within $24 \mathrm{~h}$ are, in fact, positioned in the first quadrant of the PCA, showing the greatest intensities of positive attributes such as the aroma of olive fruity and green notes and bitterness. The small percentage of oil samples that, despite having been transformed within $24 \mathrm{~h}$, are positioned in the fourth quadrant relative to the presence of sensory defects, is probably attributable to oils produced from overripe olives [32]. 
PC1 and PC2 $91.39 \%$

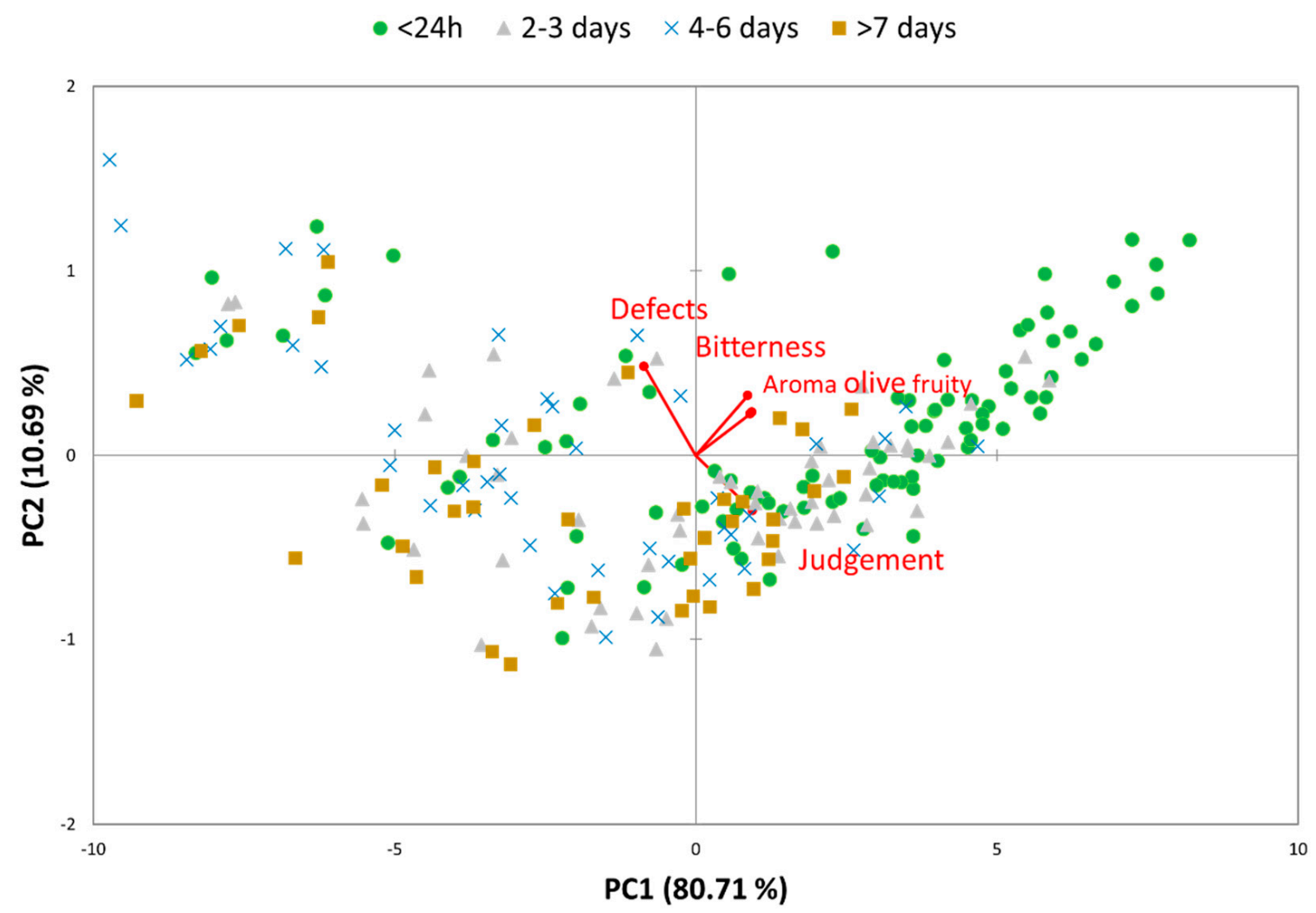

Figure 1. Principal component analysis (PCA) plot of sensory data.

\section{Conclusions}

The objective of this study, unlike other studies which investigated preprocessing storage as a way to modulate a positive reduction in the bitter taste of phenol-rich varieties with the aim of improving consumer acceptance [31], was to identify the criticality of the olive storage phase, highlighting its influence on the depletion of the EVOOs' chemical and sensory characteristics.

The authors are aware that this experimental design included many variables that affect the final quality of the oil: cultivar, ripeness, cultivation environment, seasonality and variation of technological parameters of extraction. However, thanks to the high rate of sampling, repeated for three consecutive production years, the single effect of the different variables was reduced. From this study, it emerged that some quality, nutritional and sensory parameters were affected by olive storage duration, independent of the varietal composition of the starting material. However, variety and ripeness degree influence the time window available to leave the olives on trees [33]. The knowledge of the effect of the harvest time window (early harvest or late harvest) on the olive oil final quality is important especially in years with late fly attacks, when it is recommended to harvest early rather than treating with chemicals, since a sustainable olive growing satisfies consumers who are increasingly attentive to the consumption of genuine and healthy products.

This study was carried out on purpose in a practical context characterized by all the limits listed above, thus the results provide an important photograph of the critical points of the olive storage phase from harvesting to pressing. By acting on the critical points, it is possible to improve the chain of olive oil production.

Free acidity, peroxide number, K232, total phenols, stability, $\alpha$-tocopherol, lutein, $\beta$ carotene and organoleptic properties significantly decreased between the first and second storage interval, thus after $24 \mathrm{~h}$ of olive storage the final EVOO's quality was already substantially impoverished. Many specifications for PDO and PGI productions indicate 
$48 \mathrm{~h}$ as the maximum allowed storage duration; however, it is important to underline that by keeping storage within $24 \mathrm{~h}$ it is possible to maximize the potential of the olives, thus producing the oils with the highest nutritional and sensory properties expected by selecting cultivars known for the high quality of the final product. While PDO and IGP oils are produced according to strict production regulations, this study is aimed at blends productions that represent most of the processed olives in all of the Italian regions: for this kind of production the improving of the crucial phase of olive storage duration is important, and the results of this study are clearly significant for their applicability. The purpose of this work was to provide guidelines for obtaining a high-quality product at the time of processing, initial high quality being pivotal during the oil storage phase. The associations of olive producers guarantee their associates the supply of plastic aerated bins, together with guidelines aimed at reducing the olives' storage times from harvesting to processing. Ensuring the chemical and sensory oil quality during shelf life is, in fact, becoming the purpose of the most recent labeling regulations [34]: the community regulation states that what is indicated on the label should correspond with what is expected at the end of the product's shelf life.

Supplementary Materials: The following are available online at https:/ /www.mdpi.com/article/10 .3390/foods10102296/s1. Table S1: Definition of sensory descriptors.

Author Contributions: Conceptualization, A.R.; methodology, A.R., G.B.; formal analysis, L.M., G.B.; investigation A.R., G.B.; resources, A.R., G.B.; data curation, A.R., G.B.; writing-original draft preparation, A.R., L.M.; writing—review and editing, L.N., G.B.; supervision, A.R.; project administration, A.R. All authors have read and agreed to the published version of the manuscript.

Funding: This research received no external funding.

Acknowledgments: The authors gratefully thank Matteo Mari for his technical support, Massimiliano Magli for his support in the statistical analysis, the panel of ASSAM-Marche for sensory analysis and Simon Brown for providing language help.

Conflicts of Interest: The authors declare no conflict of interest.

\section{References}

1. Tarapoulouzi, M.; Skiada, V.; Agriopoulou, S.; Psomiadis, D.; Rébufa, C.; Roussos, S.; Theocharis, C.R.; Katsaris, P.; Varzakas, T. Chemometric Discrimination of the Geographical Origin of Three Greek Cultivars of Olive Oils by Stable Isotope Ratio Analysis. Foods 2021, 10, 336. [CrossRef]

2. EU. Council regulation (EC) No 1513/2001 of 23 July 2001 amending Regulations No 136/66/EEC and (EC) No 1638/98 as regards the extension of the period of validity of the aid scheme and the quality strategy for olive oil. Off. J. Eur. Union 2001, L201, $4-7$.

3. Fregapane, G.; Salvador, M.D. Production of superior quality extra virgin olive oil modulating the content and profile of its minor components. Food Res. Int. 2013, 54, 1907-1914. [CrossRef]

4. García, J.M.; Yousfi, K. The postharvest of mill olives. Grasas Aceites 2006, 57, 16-24. [CrossRef]

5. Clodoveo, M.L.; Delcuratolo, D.; Gomes, T.; Colelli, G. Effect of different temperatures and storage atmospheres on Coratina olive oil quality. Food Chem. 2007, 102, 571-576. [CrossRef]

6. Gutierrez, F.; Perdiguero, S.; Garcia, J.M.; Castellano, J.M. Quality of oils from olives stored under controlled atmosphere. J. Am. Oil Chem. Soc. 1992, 69, 1215-1218. [CrossRef]

7. García, J.M.; Gutiérrez, F.; Castellano, J.M.; Perdiguero, S.; Morilla, A.; Albi, M.A. Influence of storage temperature on fruit ripening and olive oil quality. J. Agric. Food Chem. 1996, 44, 264-267. [CrossRef]

8. Dourtoglou, V.G.; Mamalos, A.; Makris, D.P. Storage of olives (Olea europaea) under $\mathrm{CO}_{2}$ atmosphere: Effect on anthocyanins, phenolics, sensory attributes and in vitro antioxidant properties. Food Chem. 2006, 99, 342-349. [CrossRef]

9. Koprivnjak, O.; Procida, G.; Zelinotti, T. Changes in the volatile components of virgin olive oil during fruit storage in aqueous media. Food Chem. 2000, 70, 377-384. [CrossRef]

10. Yousfi, K.; Weiland, C.M.; García, J.M. Effect of harvesting system and fruit cold storage on virgin olive oil chemical composition and quality of superintensive cultivated 'Arbequina'olives. J. Agric. Food Chem. 2012, 60, 4743-4750. [CrossRef]

11. Skiada, V.; Tsarouhas, P.; Varzakas, T. Comparison and Discrimination of Two Major Monocultivar Extra Virgin Olive Oils in the Southern Region of Peloponnese, According to Specific Compositional/Traceability Markers. Foods 2020, 9, 155. [CrossRef]

12. EEC. Commission regulation (EEC) No 2568/91 of 1July of 1991 on the characteristics of olive oil and olive-residue oil and on the relevant methods of analysis. Off. J. Eur. Comm. 1991, L248, 1-114. 
13. Cerretani, L.; Bendini, A.; Biguzzi, B.; Lercker, G.; Gallina Toschi, T. Stabilità ossidativa di oli extravergini di oliva ottenuti con diversi impianti tecnologici. Ind. Aliment. 2003, 42, 706-711.

14. Rotondi, A.; Bertazza, G.; Magli, M. Effect of olive fruits quality on the natural antioxidant compounds in extravirgin olive oil of Emilia-Romagna region. Prog. Nutr. 2004, 6, 139-145.

15. Bendini, A.; Gallina Toschi, T.; Lercker, G. Determinazione dell'attività antiossidante di estratti vegetali mediante Oxidative Stability Instrument (OSI). Ind. Aliment. 2001, 403, 525-529.

16. Skiada, V.; Tsarouhas, P.; Varzakas, T. Preliminary Study and Observation of "Kalamata PDO" Extra Virgin Olive Oil, in the Messinia Region, Southwest of Peloponnese (Greece). Foods 2019, 8, 610. [CrossRef] [PubMed]

17. Olias, J.M.; Garcia, J.M. Olive. In Postharvest Physiology and Storage of Tropical and Subtropical Fruits; Mitra, S.K., Ed.; CAB International: Wallingford, UK, 1997; pp. 229-243.

18. Servili, M.; Selvaggini, R.; Taticchi, A.; Esposto, S.; Montedoro, G. Volatile compounds and phenolic composition of virgin olive oil: Optimization of temperature and time of exposure of olive pastes to air contact during the mechanical extraction process. $J$. Agric. Food Chem. 2003, 51, 7980-7988. [CrossRef] [PubMed]

19. Vichi, S.; Romero, A.; Gallardo-Chacón, J.; Tous, J.; López-Tamames, E.; Buxaderas, S. Volatile phenols in virgin olive oils: Influence of olive variety on their formation during fruits storage. Food Chem. 2009, 116, 651-656. [CrossRef]

20. Youssef, O.; Guido, F.; Manel, I.; Youssef, N.B.; Cioni, P.L.; Mohamed, H.; Daoud, D.; Mokhtar, Z. Volatile compounds and compositional quality of virgin olive oil from Oueslati variety: Influence of geographical origin. Food Chem. 2011, 124, 1770-1776. [CrossRef]

21. Pereira, J.A.; Casal, S.; Bento, A.; Oliveira, M.B.P.P. Influence of olive storage period on oil quality of three portuguese cultivars of Olea europea, Cobrançosa, Madural, and Verdeal Transmontana. J. Agric. Food Chem. 2002, 50, 6335-6340. [CrossRef]

22. Lombardo, N.; Marone, E.; Alessandrino, M.; Godino, G.; Madeo, A.; Fiorino, P. Influence of growing season temperatures in the fatty acids (FAs) of triacilglycerols (TAGs) composition in Italian cultivars of Olea europaea. Adv. Hortic. Sci. 2008, 22, 49-53.

23. Youssef, N.B.; Leilla, A.; Youssef, O.; Mohamed, S.N.; Nizard, D.; Chedly, A.; Mokhtar, Z. Influence of the site of cultivation on Chétoui olive (Olea europaea L.) oil quality. Plant Prod. Sci. 2012, 15, 228-237. [CrossRef]

24. Gutierrez, F.; Varona, I.; Albi, M.A. Relation of acidity and sensory quality with sterol content of olive oil from stored fruit. $J$. Agric. Food Chem. 2000, 48, 1106-1110. [CrossRef] [PubMed]

25. Traber, M.G.; Atkinson, J. Vitamin E, antioxidant and nothing more. Free Radic. Biol. Med. 2007, 43, 4-15. [CrossRef] [PubMed]

26. Rastrelli, L.; Passi, S.; Ippolito, F.; Vacca, G.; De Simone, F. Rate of degradation of $\alpha$-tocopherol, squalene, phenolics, and polyunsaturated fatty acids in olive oil during different storage conditions. J. Agric. Food Chem. 2002, 50, 5566-5570. [CrossRef] [PubMed]

27. Rotondi, A.; Lapucci, C. Nutritional properties of extra virgin olive oils from the Emilia-Romagna region: Profiles of phenols, vitamins and fatty acids. In Olives and Olive Oil in Health and Disease Prevention; Preedy, V.R., Watson, R.R., Eds.; Academic Press: Burlington, MA, USA, 2010; pp. 725-733.

28. Criado, M.N.; Motilva, M.J.; Goni, M.; Romero, M.P. Comparative study of the effect of the maturation process of the olive fruit on the chlorophyll and carotenoid fractions of drupes and virgin oils from Arbequina and Farga cultivars. Food Chem. 2007, 100, 748-755. [CrossRef]

29. Jabeur, H.; Zribi, A.; Abdelhedi, R.; Bouaziz, M. Effect of olive storage conditions on Chemlali olive oil quality and the effective role of fatty acids alkyl esters in checking olive oils authenticity. Food Chem. 2015, 169, 289-296. [CrossRef]

30. Psomiadou, E.; Tsimidou, M. Pigments in Greek virgin olive oils: Occurrence and levels. J. Sci. Food Agric. 2001, 81, 640-647. [CrossRef]

31. Inarejos-Garcia, A.M.; Gomez-Rico, A.; Desamparados Salvador, M.; Fregapane, G. Effect of preprocessing olive storage conditions on virgin olive oil quality and composition. J. Agric. Food Chem. 2010, 58, 4858-4865. [CrossRef]

32. Morales, M.T.; Luna, G.; Aparicio, R. Comparative study of virgin olive oil sensory defects. Food Chem. 2005, 91, 293-301. [CrossRef]

33. Morrone, L.; Rotondi, A.; Rapparini, F.; Bertazza, G. Olive Processing: Influence of Some Crucial Phases on the Final Quality of Olive Oil. In Food Processing; Marc, R.A., Valero Díaz, A., Posada Izquierdo, G.D., Eds.; IntechOpen: London, UK, 2019; pp. 29-46.

34. EU. Commission delegated regulation (EU) 1096/2018 of 22 May 2018 amending Implementing Regulation (EU) No 29/2012 as regards the requirements for certain indications on the labelling of olive oil. Off. J. Eur. Union 2018, L197, 4-5. 